Frane Martinić

Gojmir Radica

Frano Barbir

http://dx.doi.org/10.21278/brod69405

\title{
APPLICATION AND ANALYSIS OF SOLID OXIDE FUEL CELLS IN SHIP ENERGY SYSTEMS
}

UDC 629.5.038:629.545

Original scientific paper

\begin{abstract}
Summary
This study identifies and analyses the overall energy consumption required for converting LNG (liquefied natural gas) from liquid to gaseous state in high pressure vaporizers at various cargo discharge rates on a liquid natural gas regasification vessel (LNGRV). The actual measured data were collected on an available vessel, to calculate the overall energy consumption of converting natural gas from liquid to gaseous state by three built-in turbo generators. Next, the study considers their replacement with the newest innovative technology including three solid oxide fuel cell (SOFC) power plants of the same power. This paper provides a simplified analysis of the proposed implementation of the SOFC power plant which was performed for the first time in the existing literature. The results show a significant increase in the achievable electrical efficiency of $40.6 \%$, with respect to $32.9 \%$ of a system with turbo generators. The research has also shown that waste heat from the SOFCs can be used to produce thermal energy, resulting in further savings of $2.6 \%$ in natural gas consumption. Future research could be done on other regasification terminals in the world, which use different main propulsion technology, using an open, closed or combined cycle during the regasification operations.
\end{abstract}

Key words: $L N G$ (liquid natural gas); LNGRV (liquid natural gas regasification vessel); Regasification unit; High pressure manifold; SOFC (solid oxide fuel cell)

\section{Introduction}

A total of $452 \mathrm{LNG}$ tankers are currently working around the world. The difference is based on the propulsion of the LNG tankers. According to the latest data from [1,2], 262 LNG tankers can be found with a steam turbine propulsion, $112 \mathrm{LNG}$ tankers with a dual fuel diesel electric propulsion, $50 \mathrm{LNG}$ tankers with a diesel engine propulsion and a re-liquefaction plant, 25 tankers with a three fuel diesel electric propulsion, 3 LNG tankers with a marine engine gas injection propulsion and $1 \mathrm{LNG}$ icebreaking class tanker with a diesel engine propulsion. 74 new LNG tankers were ordered with different propulsions till 01.04.2020.

The advent of LNG as a marine fuel is triggered by the efforts of policy makers to abate environmental burdens from the exhaust gases of ships. A thorough outline of the regulatory 
environment triggering the use of alternative fuels in ships and, therefore, maritime networks, is presented in literature [3]. It seems evident that air emission regulations will continue to demand that ships reduce emission and increase operational efficiency. Hence, policy and technology evolution and market initiatives are expected, which is a promising set of conditions for the market acceptance of LNG-fuelled ships [3]. The growing demand for energy sources in the global framework, particularly for LNG, has led to the development and construction of Liquefied Natural Gas Regasification Vessels (LNGRVs). This type of an LNG carrier is specific for its compatibility with all the existing terminals (loading and discharging) in the world. Furthermore, along with its conventional purpose of loading, transporting, and discharging LNG (in liquid state), it is fitted with a built-in regasification unit at the bow area, i.e. a unit which converts LNG from liquid to gaseous state, hence distributing compressed gas ashore through a high pressure terminal pipeline (connecting to it through a high pressure manifold on the carrier deck). So far, eight carriers using this technology have been built in the world. They are named LNGRVs, and are mostly owned by the US company Excelerate Energy. Each of the eight LNGRV carriers has their own propulsion plant (steam turbine) which enables them to sail, but they can also be used as ships for cargo storage and regasification [4]. Figure 1 shows a LNGRV tanker connected to the discharging terminal [5].

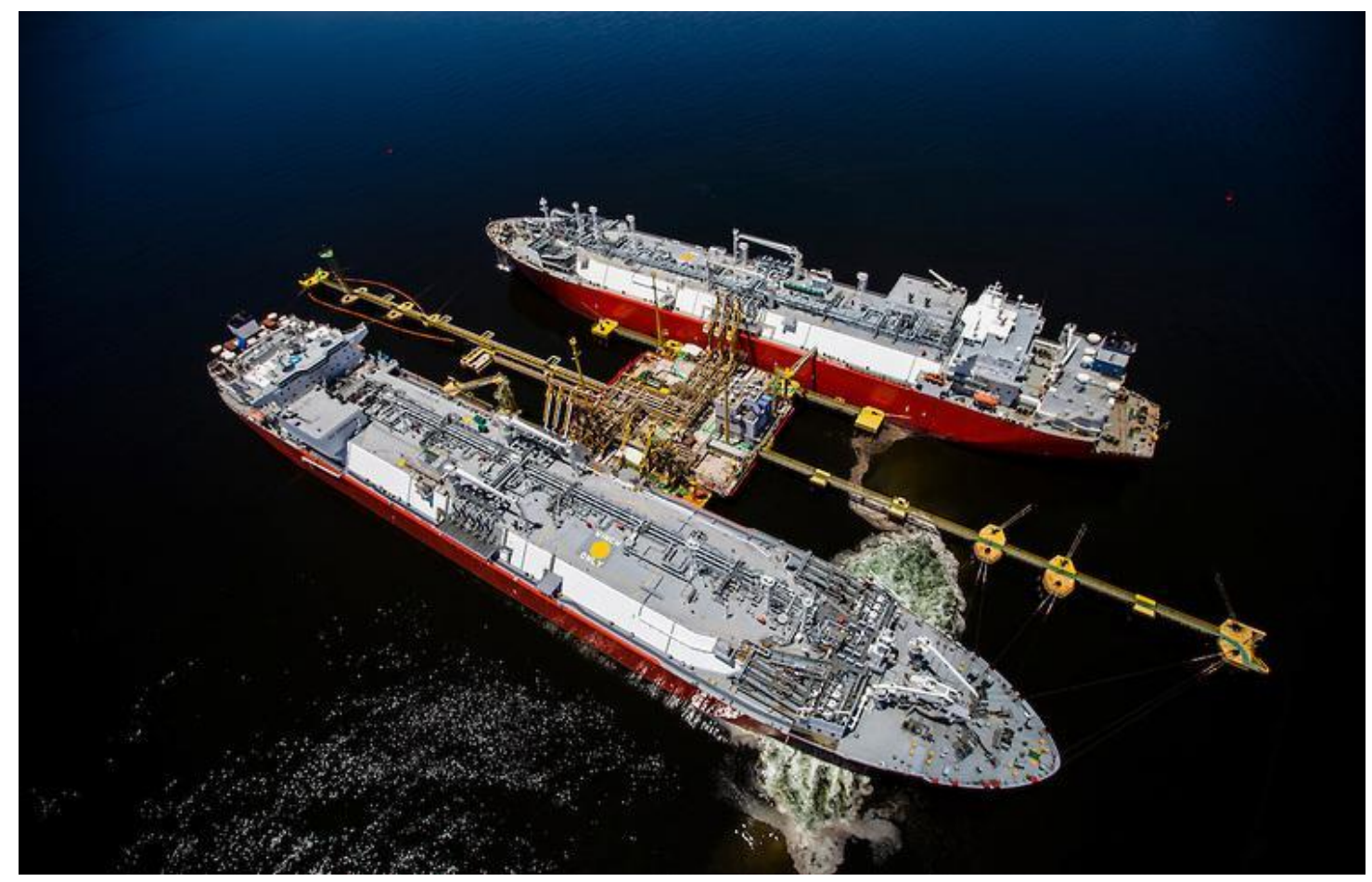

Fig. 1. LNGRV tanker connected to the discharging terminal [5]

The paper describes the functioning of a regasification system, particularly the regasification system used on an LNGRV, and the means of discharging compressed gas through an open loop high pressure manifold, in which relatively warm seawater is used as the heat source. The seawater passes through a high pressure vaporizer, causing the vaporization of LNG.

LNGRVs are capable of providing a continuous compressed gas discharge amount to the consumers, ranging from 50 to 800 MMSCFD (Million Standard Cubic Feet per Day) at atmospheric pressure and the temperature of $15.56^{\circ} \mathrm{C}$. One million standard cubic feet per day equals $1,116.28 \mathrm{~m}^{3} / \mathrm{h}$ (the volume, in $\mathrm{m}^{3}$, is given at $0{ }^{\circ} \mathrm{C}$ and $100 \mathrm{kPa}$ ). For the purpose of 
calculating a natural gas volume, necessary for calculating and determining the gas energy value, standard conditions for temperature and pressure are used. Accordingly, it follows that the compressed gas discharge flow at LNGRVs ranges from 1.34 million $\mathrm{m}^{3} / \mathrm{d}$ to 21.43 million $\mathrm{m}^{3} / \mathrm{d}$.

The technology of LNG vaporization on LNGRVs implies the usage of water (sea or fresh water) in high pressure vaporizers aiming to change the aggregate state of LNG. A schematic diagram of the regasification process is shown in Fig. 2. The main component parts of the regasification unit system on an LNGRV are: 3 feed cargo pumps, a suction drum, 2 small high pressure pumps, 6 high pressure pumps, 6 high pressure vaporizers, a metering unit, 2 control valves, and a high pressure pipeline. All these components are used for the LNG regasification. In addition, the auxiliary system comprises 3 steam heaters, 3 ballast pumps, and 3 circulating pumps. LNG is stored in the cargo tanks at a pressure slightly above atmospheric pressure and is pumped by small high pressure feed pumps to the suction drum. From the suction drum the liquid pressure is increased through pumping by the high pressure pumps to the vaporizers. The regasification is achieved by passing the liquid through the water heated shell and tube vaporizers, the gas then being sent to the distribution network onshore through a high pressure manifold. The high pressure pumps increase the pressure of the LNG from the suction drum to the vaporizers, to a pressure in excess of 100 bars. The gas is then metered and passed via a back pressure control valve, through an emergency shutdown valve and is in turn directed to the high pressure manifold discharge connection. The purpose of the auxiliary heating water system is to supply heating water to the vaporizers and, if required, to heat up the heating water up to the required temperature in case of operation in a closed or combined mode. An LNG vaporizer, a shell and tube type, has been designed to cope with the high thermal shrinkage due to the cold LNG and corrosion against sea water. The piping system connected to the inlet and outlet of the vaporizer has been designed to have sufficient flexibilities so that excessive nozzle forces are not exerted to the vaporizer. The vaporizer has been designed to operate in the supercritical pressure of the natural gas. In general, the heating water outlet from the LNG sides is at a lower temperature than the natural gas side [4].

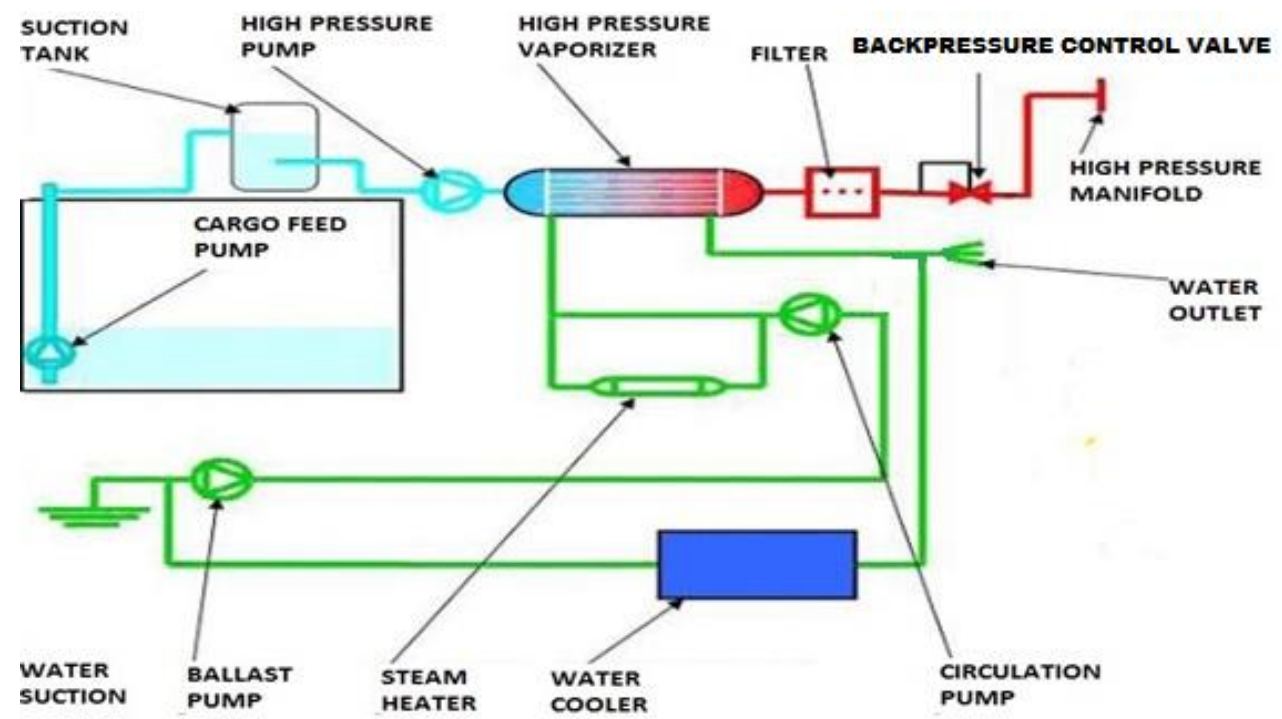

Fig. 2. Schematic presentation of regasification process [4]

The ship's main boilers produce the superheated steam necessary for driving 3 turbo generators that have to ensure enough electrical energy for running the ship machinery and for driving the engines and devices that partake in the regasification process. The ship's main 
boilers (steam generators) use exclusively natural gas as fuel, which is brought to the boilers by a low pressure compressor through the steam heater located in the ship's compressor room.

Liquefied natural gas (LNG) fuelled shipping systems adopts the boil-off gas (BOG) reliquefaction process to maintain the pressure of the storage tank and to minimize methane loss [6].

Fuel cells may provide a suitable solution to reduce the environmental impact of the ship's operations, since they are fuel efficient emitting few hazardous compounds. The expanding infrastructure of liquefied natural gas and development state of natural gas-fuelled fuel cell systems can facilitate the introduction of fuel cells on ships. Fuel cell combined cycles, hybridisation with auxiliary electricity storage systems and redundancy improvements are identified as topics for further studies [7].

The aim of this paper is to analyse energy efficiency when replacing the existing turbo generators by the Solid Oxide Fuel Cells (SOFCs). Instead of three turbo generators (each of the power of $3,700 \mathrm{~kW}$ ), three SOFCs (each of the power of 3,700 kW) would be installed in the steam plant for producing electrical energy.

Yousri et al., analysed a combined system consisting of a solid oxide fuel cell (SOFC) and a steam turbine system which utilizes the energy transported with the exhaust gas leaving the fuel cell operated in ship power plants [8]. It is found that a high overall efficiency approaching $60 \%$ may be achieved with an optimum configuration using SOFC system. In another study [9], steam and SOFC based reforming options of natural gas for PEM fuel cells are proposed as an attractive option to limit the environmental impact of the marine sector. It is found that a high overall efficiency approaching $60 \%$ may be achieved using SOFC based reforming systems which are significantly better than a reformed PEM system or an SOFC only system.

A conceptual design of the SOFC for a $250 \mathrm{~kW}$ CHP (Combine heat and power) application [10], has spurred the group of authors to develop a hybrid system with diesel engines and two SOFCs to produce electricity on supplier vessels [11].

Energy analysis of the SOFC, fuelled by methane [12,13], then the distribution of electric power generated by SOFCs [14], and an analysis of energy and exergy reformation of methane using steam [15-17], provide the first concept for the use of SOFCs for production of electricity on an LNG tanker with steam propulsion. On an LNG tanker transporting natural gas, a main turbine uses superheated steam to run. These facts are advantages and therefore have a positive reflection on the research of combined steam propulsion systems with SOFCs. The steam produced from the ship's boilers is used for natural gas reformation to produce hydrogen for the SOFC.

A thermodynamic analysis of a Brayton cycle and a Rankine cycle with the fuel cell experimental data $[18,19]$ and exergetic analysis applied to a combined cycle power plant has an inclination $[20,21]$ for saving energy if it is electricity generated by the SOFC. According to [22-24], the integration of a hybrid SOFC with gas turbines was investigated, where an analysis of energy, exergy and exergo-economic of cogeneration of heat was completed and a similar one could implement a combination of the SOFC with the steam turbine plant.

This research did not include a combined and a closed cycle for both commercial reasons and the impossibility to use steam heaters during the regasification operation due to the continuous high temperature of the sea water in the location where the measurements were taken.

Diesel-electric propulsion systems with heat utilization can achieve even higher efficiency but our goal is to improve efficiency on the steam turbine propulsion ships. The benefits of the proposed power system configuration is achieved on an LNG tanker transporting natural gas with combined steam propulsion systems that include SOFCs. 


\section{Description of an open loop regasification system}

A similar issue is published in [25] where aim of the study has been to determine the energy consumption required to liquefied natural gas from liquid into a gas at high pressure evaporators at different instalments of discharging cargo. This research was conducted for the gas terminal Mina Al Ahmadi Gas Port in Kuwait, and the results were monitored during the discharge in May 2011. The paper describes the functioning of the regasification system. The basic principle of the system for gasification of tankers to transport liquefied natural gas has been described too. The results of this study can be used to compare the energy consumption in the conversion of gas from a liquid to a gaseous state to the other terminals that use the services of ships for transporting liquefied natural gas plant with integrated gasification, and to analyse the energy consumption of conventional unloading of liquefied natural gas terminal. During this research, the consumed energy obtained data were only measured in the open cycle because the system was limited by sea temperature of around $25^{\circ} \mathrm{C}$ during May 2011.

This paper deals with new SOFC technology that can be used instead of a turbo generator to produce the electricity needed for the regasification process on LNGRV carrier.

It should be noted that the analysis was performed with the data collected from the existing LNGRV carrier. Also, another analysis should be carried out in the future with different LNG carriers using new propulsion technologies.

The functioning of a regasification system was monitored on the LNGRV Exquisite carrier during the discharge period from early January to late April 2014 at the Guanabara Bay LNG Import Terminal just outside of Rio de Janeiro in Brazil. Throughout the period in question, the average seawater temperature ranged from $22{ }^{\circ} \mathrm{C}$ to $26^{\circ} \mathrm{C}$. Such seawater temperature enabled the regasification process to be carried out in an open loop, i.e. the cargo in the high pressure vaporizers was heated by seawater, without using the steam heaters. The placement of the pumps and pipelines on the carrier allowed for the achievement of the desired compressed gas output pressure, which was dependant on the current demands of the consumers ashore. The regasification and the compressed gas discharge process were conducted without suspension while the liquefied natural gas from another LNG carrier was being loaded to the LNGRV Exquisite carrier.

For the LNGRV Exquisite's regasification process and cargo discharge, commonly 2 seawater ballast pumps, 2 seawater circulating pumps, 2 feed cargo pumps, 5 high pressure cargo pumps and 5 high pressure vaporizers were used.

The discharge flow ranged from $111,628 \mathrm{~m}^{3} / \mathrm{h}$ to $893,024 \mathrm{~m}^{3} / \mathrm{h}$. The seawater was passing through 6 high pressure vaporizers with the minimal flow of $1,800 \mathrm{~m}^{3} / \mathrm{h}$ in order to avoid the high pressure vaporizers' freezing, i.e. the vaporizers were ready for use at any instance. During the maximum discharge flow of $893,024 \mathrm{~m}^{3} / \mathrm{h}$, it was necessary to turn on 3 seawater ballast pumps, 3 seawater circulating pumps, 3 feed cargo pumps, 6 high pressure cargo pumps, 6 high pressure vaporizers, and the diesel motor (that uses natural gas for fuel), which significantly increased the natural gas consumption [4].

In order for a regasification unit system to start working, the first task would be to cool down the pipelines and other units that partake in the process. LNG is supplied to the pipeline leading from the cargo tank to the suction drum, and inside the suction drum itself, through a 
small spray nozzle installed in the cargo tank. The part of the unit leading from the suction drum to the vaporizer has to be cooled down and brought to a working pressure by using a small high pressure pump with a design capacity of $20 \mathrm{~m}^{3} / \mathrm{h}$ and discharge pressure of 237 bars.

A feed pump pressures the LNG from the cargo tank towards the suction drum. Each feed pump has a design capacity of $620 \mathrm{~m}^{3} / \mathrm{h}$, and discharge pressure of 15.5 bars. The suction drum volume is $17 \mathrm{~m}^{3}$. At normal system activity, the suction drum working pressure is $0.35 \mathrm{MPa}$. The LNG takes about 55\% of the suction drum total capacity. By free falling, the LNG reaches the suction side of a high pressure pump with a design capacity of $205 \mathrm{~m}^{3} / \mathrm{h}$, and discharge pressure of 237 bars. The high pressure pump brings the LNG to the pressure of $10 \mathrm{MPa}$ and pressures it towards the high pressure vaporizer, where the aggregate state of the LNG changes from liquid to gaseous.

Water temperature is a very important factor in the process of cargo regasification in high pressure vaporizers. The water for vaporizing LNG circulates through a high pressure vaporizer in an open loop, without being heated with steam heaters. With such open loop systems, the sea water is fed from the pumps (with a design capacity of $5,000 \mathrm{~m}^{3} / \mathrm{h}$ ) located in the ship's engine room, and transported towards the circulating pumps (with a design capacity of $5,000 \mathrm{~m}^{3} / \mathrm{h}$ ) that force the water towards the high pressure vaporizers, and finally to an overboard discharge. Throughout the process, the water temperature decreases by about $7{ }^{\circ} \mathrm{C}$. The input water temperature in a high pressure vaporizer must not be lower than $5^{\circ} \mathrm{C}$, with a minimum water flow of $1,800 \mathrm{~m}^{3} \mathrm{~h}^{-1}$ for each high pressure vaporizer.

Throughout the process, the water temperature lowers by about $7{ }^{\circ} \mathrm{C}$. The input water temperature in a high pressure vaporizer must not be lower than $14.7^{\circ} \mathrm{C}$, with a minimum water flow of $1,800 \mathrm{~m}^{3} / \mathrm{h}$ for each high pressure vaporizer. In an open loop the minimum heating water flow to each vaporizer is designed to avoid any possibility of the loss of the heating water flow and the resulting greater risk of icing up a vaporizer.

The compressed gas travels from the vaporizers towards the metering unit, which measures the compressed gas flow, temperature, pressure, and composition. Following the metering unit, there is a control valve built in the high pressure pipeline, which regulates the compressed gas output pressure to somewhere between 7 and $10 \mathrm{MPa}$. The compressed gas travels towards a high pressure terminal ashore. The control over the entire system is based on the following 3 parameters: discharge rate (demanded cargo quantity), maximum pressure, and minimum temperature of the compressed gas to be discharged [4].

\section{Natural gas consumption during regasification and discharging process}

During this research on energy consumption, the obtained data were exclusively measured at the open loop, as the system was limited by the seawater temperature of $22{ }^{\circ} \mathrm{C}$ to $26{ }^{\circ} \mathrm{C}$ as stated above. All the data measured were taken from sophisticated, calibrated and certified devices installed on this type of carrier. The Fuel Gas Flow Turbine Meter devices were used for measuring the compressed gas discharge flow and the consumption of natural gas in the main boilers, and the obtained data were sent every 15 seconds to the data collection unit, Flow Counter M3000. This device shows the data on the screen immediately, and prints them out hourly every day. The data printed by the device were used in this research. The data gathered (15-samples) did not differ significantly from one another, so the arithmetic mean was used for calculating the average value. It has all the necessary properties which characterize measures of central tendency, as well as additional properties significant for its application.

The graph in Figure 3 shows the need to produce electrical energy and the overall gas consumption of the steam-turbine plant in dependency on the value of natural gas discharge flow. The need to produce electrical energy proportionally increases to the rate of $669,768 \mathrm{~m}^{3} / \mathrm{h}$ 
and starts rapidly growing when it exceeds this value. The reason behind this is the turning on of another seawater ballast pump, seawater circulatory pump, feed cargo pump, high pressure cargo pump, and the diesel motor. Accordingly, the increased production of electrical energy in the ship's engine room leads to an increased consumption of natural gas which is combusted in the ship's main boilers, but also, at the discharge rate of $669,768 \mathrm{~m}^{3} / \mathrm{h}$ in the diesel engine which uses natural gas for fuel. The ship's main boilers produce the superheated steam needed to run the turbo generators, which is connected to an alternator through a reduction gear box, and is used for producing the needed electrical energy. The ship has a total of 3 built-in turbo generators and 3 alternators for producing electrical energy of a total of 11.1 MW. For producing additional energy, the diesel generator with the power of $3.5 \mathrm{MW}$ is used. Only the use of a diesel generator significantly increases the consumption of natural gas during the discharge rate greater than $669,768 \mathrm{~m}^{3} / \mathrm{h}[4]$.

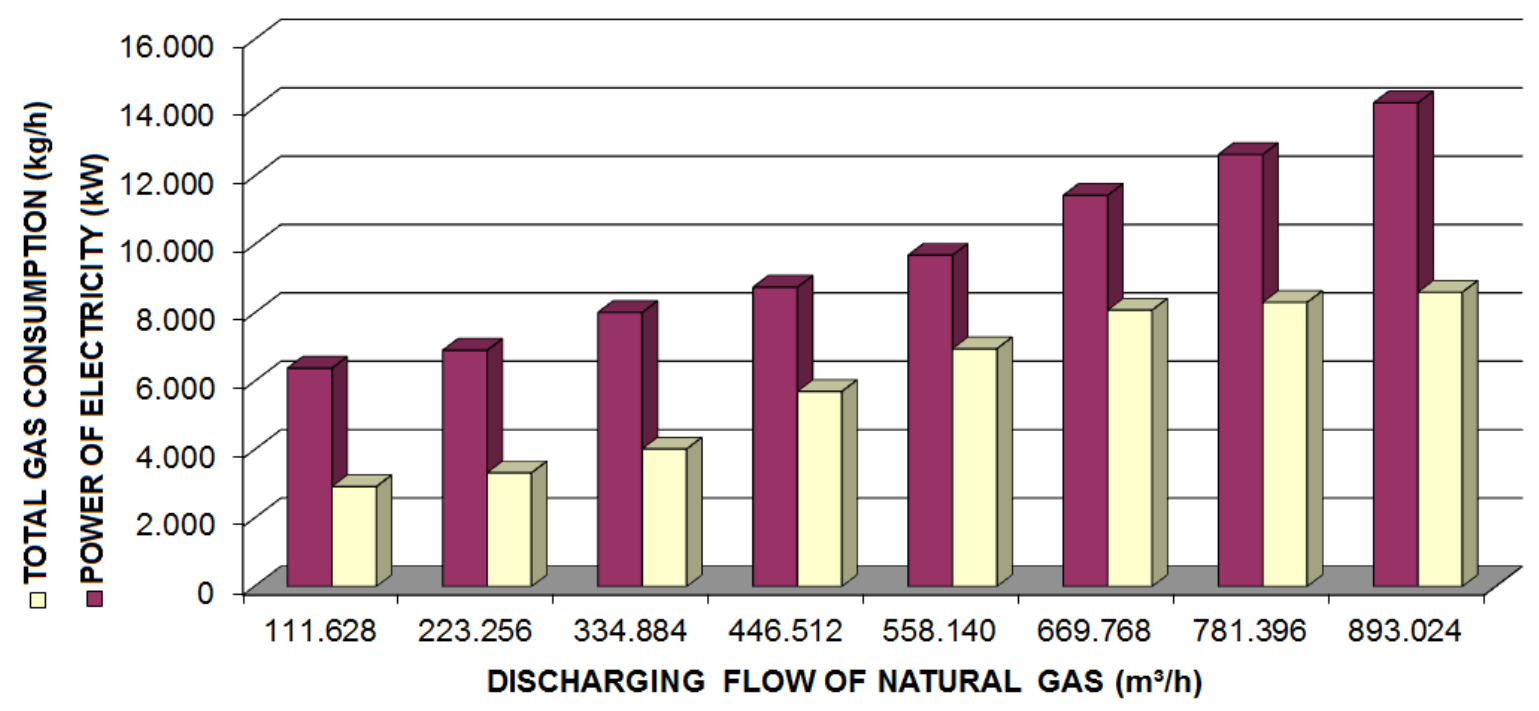

Fig. 3. The amount of electricity generated and total gas consumption as a function of discharging flow of natural gas

\section{Potential application of solid oxide fuel cell on LNG carriers}

Figure 4 displays a schematic representation of a hybrid system in which, instead of three turbo generators [26], three SOFCs with the same power would be installed in the steam plant for producing electrical energy, and a part of the heat produced during the fuel cell activity would be used for producing steam in the LPSG (low pressure steam generator), of up to 0.8 $\mathrm{MPa}$, in order to achieve as great system efficiency as possible. A part of the anode exhaust gases would be re-used and mixed with the steam for reforming fuel (natural gas), before entering the reformer. The remaining part of the anode exhaust gases would travel further to the combustion chamber of the main boilers, where it would combust completely. However, as this reserve would be negligible, it was not taken into consideration in this study. The combustion of anode exhaust gases is vital for reducing exhaust emission, i.e. for environmental protection.

A fuel cell power system comprises a SOFC stack [27], its main component, a fan, a compressor, a reformer, a fuel (gas) heater, and an air heater. Taking into consideration the heat 
requirements for the reactions in the reformer to occur, the gas heater raises the temperature of the fuel before it reaches the reformer itself. Before entering the fuel cell stack, the gas is reformed partly to hydrogen, and partly to carbon monoxide. The reactions in the reformer are ones of the system optimization parameters, and they have enormous influence on the heat balance and overall efficiency. The share of carbon that enters into a fuel cell (external reaction) and the minimum flow of oxygen for cooling down the fuel cell stack (internal reaction) have to be regulated and achieved by a certain degree of reformation [28]. The methane present in the system cannot electrochemically oxidize, but only reform into hydrogen, carbon monoxide or carbon dioxide. The reactions occurring in the steam reformer are steam reforming (1), water-shift reaction (2) and reaction occurring in the fuel cell is electrochemical reaction (3) [25]:

$$
\begin{array}{ll}
\mathrm{CH}_{4}+\mathrm{H}_{2} \mathrm{O} \leftrightarrow \mathrm{CO}+3 \mathrm{H}_{2} & (\Delta \mathrm{H}=-206 \mathrm{~kJ} / \mathrm{mol}) \\
\mathrm{CO}+\mathrm{H}_{2} \mathrm{O} \leftrightarrow \mathrm{CO}_{2}+\mathrm{H}_{2} & (\Delta \mathrm{H}=41 \mathrm{~kJ} / \mathrm{mol}) \\
\mathrm{H}_{2}+1 / 2 \mathrm{O}_{2} \leftrightarrow \mathrm{CO}+3 \mathrm{H}_{2} &
\end{array}
$$

Compressed air is heated before supplied to a fuel cell A fuel cell comprises two ribbed bipolar plates, an anode, an electrolyte, and a cathode [29]. The bipolar plates are used to separate as many individual cells as possible, and to electrically stack them in series, at the same time bringing gas to the anode and air to the cathode. The ribbed bipolar plates have a flat surface in between the catalyst layers, so that they adhere better to the surface. An electrical potential evolves on the anode and cathode, i.e. a voltage by means of which we generate electrical energy [27].

The temperature of air upon being fed into a fuel cell (cathode) is about $500{ }^{\circ} \mathrm{C}$, while it rises to about $800^{\circ} \mathrm{C}$ when leaving the cell (cathode). Upon leaving the anode of the cell, the temperature of the propulsion fuel is about $800{ }^{\circ} \mathrm{C}$. Following the electrochemical reaction, a part of the anode exhaust gases travel further to the combustion chamber of the steam generator, where it combusts completely with the help of additional quantities of air and fuel.

According to [30], such hybrid systems with fuel cells can generate the output power of up to $29.6 \mathrm{MW}$, by consuming $1.19 \mathrm{~kg} / \mathrm{s}$ of natural gas, with the efficiency of up to $60 \%$. Also, $5 \%$ losses due to electrical power conversion should be taken into account [30].

The SOFC generates direct current. For driving a ship's electromotor, alternating current of 440 voltages is needed. The conversion of direct current to alternating current was not taken into consideration by this study due to the fact that, with the systems where the induced voltage is higher than $110 \mathrm{~V}$, the conversion efficiency exceeds $95 \%$ [30]. 


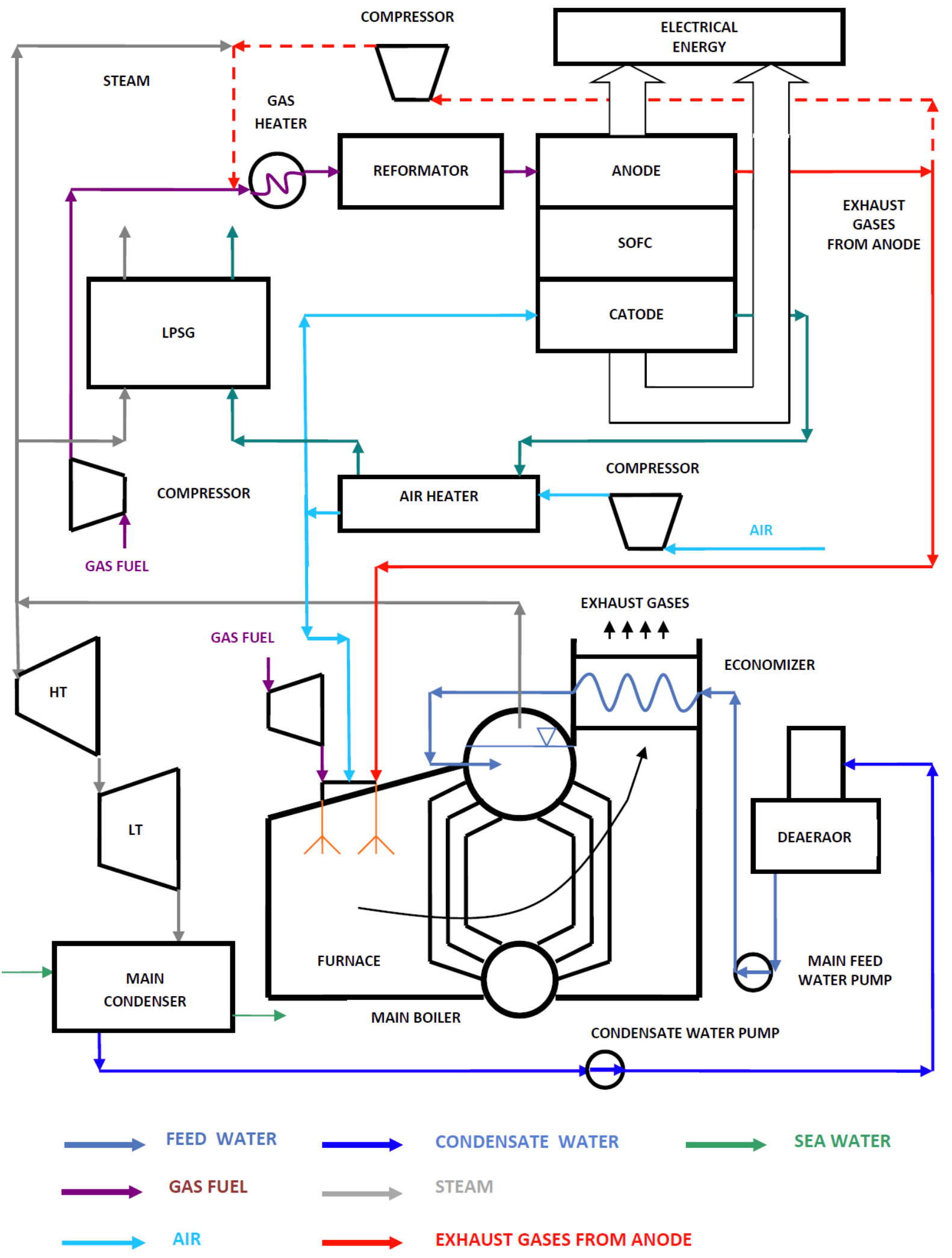

Fig. 4. The combined system for thermal and electrical energy in combination with a steam plant 


\section{Energy consumption calculation}

Measured data shown in table 1 were collected [26] and used for the energy consumption calculation.

Table 1. Input data for the calculation

\begin{tabular}{|l|c|c|}
\hline \multicolumn{1}{|c|}{ INPUT DATA } & VALUE & $\begin{array}{c}\text { UNITS OF } \\
\text { MEASURMENT }\end{array}$ \\
\hline Power electricity of turbo generator & 3.7 & MW \\
\hline Power electricity of diesel engine & 3.5 & $\mathrm{MW}$ \\
\hline $\begin{array}{l}\text { Total installed capacity of electricity (3 steam generators + 1 } \\
\text { diesel generator) }\end{array}$ & 14.6 & $\mathrm{MW}$ \\
\hline $\begin{array}{l}\text { Power electricity at maximum discharge flow of cargo (natural } \\
\text { gas) }\end{array}$ & 14.2 & $\mathrm{MW}$ \\
\hline Maximum discharge flow of cargo (natural gas) & 893,024 & $\mathrm{~m}^{3} / \mathrm{h}$ \\
\hline Consumption of natural gas to drive 1 steam generator & 730 & $\mathrm{~kg} / \mathrm{h}$ \\
\hline Density of natural gas (patm. and $15^{\circ}$ C) & 428.633 & $\mathrm{~kg} / \mathrm{m}^{3}$ \\
\hline The power produced during the operation of SOFC & 29.6 & $\mathrm{MW}$ \\
\hline Consumption of natural gas for generated power of $26,9 \mathrm{MW}$ & 1.19 & $\mathrm{~kg} / \mathrm{s}$ \\
\hline
\end{tabular}

\subsection{Calculation of natural gas consumption in producing electrical energy by a steam generator}

For producing electrical energy on LNG carriers, 3 turbo generators, and a diesel motor, which uses natural gas for fuel, were used [26]. These meet the capacity of generating the required quantity of electrical energy. The greatest amounts of electrical energy are required during a maximum compressed gas discharge flow $\left(893,024 \mathrm{~m}^{3} / \mathrm{h}\right)$, at which the electric grid load amounts are about 14.2 MW. The estimation of the natural gas consumption by the diesel engine was not taken into consideration in this study.

The overall natural gas consumption by a turbo generators and a diesel engine at various discharge rates is described at the beginning of the paper, and shown in the graph in Figure 3. For producing 3.7 MW of electrical energy, an AT42CT-B model turbo generator uses about $15,200 \mathrm{~kg} / \mathrm{h}$ of superheated steam [26], produced by an $M B-4 E K S-2$ model of the main boilers [31]. The value of the gas amount required for producing $15,200 \mathrm{~kg} / \mathrm{h}$ of superheated steam was measured during a cargo discharge, and totals about $730 \mathrm{~kg} / \mathrm{h}$ of natural gas, meaning that for 3 turbo generators to operate, about $2,190 \mathrm{~kg} / \mathrm{h}$, i.e. $52,560 \mathrm{~kg} / \mathrm{d}$ of natural gas is needed for generating electrical energy. It is important to note that natural gas densities vary depending on the natural gas composition, i.e. on the gas extraction location [26], but the arranged value of $530 \mathrm{~kg} / \mathrm{m}^{3}$ is used for estimations [31]. If we take the value of the natural gas consumption for producing electrical energy $(\mathrm{P}=3.7 \mathrm{MW})$ and divide it with the natural gas density, we get the gas amount required [26] for 3 turbo generators to operate:

$g_{3 T G}=g / \rho$ 
where:

$g$ - natural gas consumption for producing electrical energy by 3 turbo generators $[\mathrm{kg} / \mathrm{h}]$,

$\rho$ - natural gas density $\left[\mathrm{kg} / \mathrm{m}^{3}\right]$ at $\mathrm{p}_{\text {atm. }}$ and $15^{\circ} \mathrm{C}$

$g_{3 T G}=52,560 / 530=99.17 \mathrm{~m}^{3} / d$

Accordingly, it can be concluded that the overall natural gas consumption for generating electrical energy by means of 3 turbo generators amounts to $99.17 \mathrm{~m} / \mathrm{d}$.

In order to produce $15,200 \mathrm{~kg} / \mathrm{h}$ of superheated steam to generate required electrical energy, main boilers consume $\mathrm{g}_{\mathrm{P} 1}=730 \mathrm{~kg} / \mathrm{h}$ of natural gas. Higher heating value of the natural gas is $\mathrm{H}_{\mathrm{g}}=55,550 \mathrm{~kJ} / \mathrm{kg}$, by multiplying these two values we get the amount of the input power [24]:

$P_{1}=g_{P 1} * H_{g}$

$P_{1}=730 * 55,550=40,551,500 \mathrm{~kJ} / \mathrm{h}=11,264.31 \mathrm{~kW}=11,26 \mathrm{MW}$

If we divide the required power $\mathrm{P}=3.7 \mathrm{MW}$ with the input power $\mathrm{P}_{1}=11.26 \mathrm{MW}$, we get the value of a steam generator energy conversion efficiency:

$\eta_{E L 1}=P / P_{1}$

$\eta_{E L 1}=3,7 / 11.26=0.329$

\subsection{Calculation of natural gas consumption in producing electrical energy by SOFC}

The electrical energy required for all the devices on a ship to operate during a compressed gas discharge by using a regasification device can be generated by means of a SOFC stack and a diesel motor using natural gas for fuel.

By increasing the reformation degree, the hydrogen percentage increases upon entering a fuel cell, compared to the steam percentage. The same thing happens to the fuel cell voltage. In contrast to this, increasing the level of fuel efficiency leads to a greater concentration of steam, compared to the concentration of hydrogen in the exhaust gases from the anode. Therefore, this effect is repeated when the gases enter the anode through the gas recirculation flow from the anode. The recirculation ratio can also be adjusted, just like the ratio between the anode exhaust gases and steam. A high recirculation ratio causes an increase in the amount of fuel entering the fuel cell. The fuel cell voltage slowly increases when an appropriate percentage of natural gas is reformed before entering the fuel cell, due to a high hydrogen percentage and a low steam percentage in the anode exhaust gases. Since the concentration of reactants in the fuel decreases with an increase in the fuel efficiency percentage, and since the fuel cell voltage cannot exceed the lowest value in the fuel cell, the fuel efficiency percentage limits the value of the fuel cell voltage. In fact, if the percentage of hydrogen upon entering the fuel cell increases due to recirculation from the anode, the percentage of steam would still be greater when entering the same fuel cell. Furthermore, the voltage drop resulting from more steam would be evident [27].

The input temperature deviation is not shown as an important deviation from the composition of exhaust gases. In reality, decreasing the fuel cell input temperature leads to decreasing the value of carbon dioxide and monoxide, since the chemical reaction has an 
enhanced impact on the temperature decrease. During the system activity, the input temperature changes, while the output temperature remains constant and amounts to $800{ }^{\circ} \mathrm{C}$ [28].

Taking into account that power is calculated by multiplying electric current and voltage, power is constant with the input temperature, and increases with rises in the reformation degree. During simultaneous activity, i.e. by increasing current density and decreasing voltage, the fuel efficiency (efficiency of a process that converts chemical potential energy contained in a fuelMethan into electrical energy and heat) for the same power is about $80 \%$, and the anode recirculation is about $65 \%$. The greatest electrical efficiency percentage is gained when the anode recirculation is somewhere between $50-60 \%$, and the fuel efficiency percentage is $75 \%$ [27].

Considering the hybrid system with fuel cells from [30], it can produce the output power of up to $\mathrm{P}_{0}=29.6 \mathrm{MW}$, while the natural gas consumption amounts to $1.19 \mathrm{~kg} / \mathrm{s}$. If the same efficiency is assumed and by setting the simple ratio between consumption at maximum power and at part load, the following can be calculated for the natural gas consumption by the SOFC:

$g_{2 m}=g_{0} * P / P_{0}$

where:

$\mathrm{g}_{0}-$ natural gas consumption for generating $P_{0}=29.6 \mathrm{MW}$ of electrical energy produced with the SOFC $[\mathrm{kg} / \mathrm{s}]$,

$P$ - electrical energy demand [W],

$P_{0}$ - electrical energy produced with the SOFC [W],

$g_{2 m}=1.19 * 3,700,000 / 29,600,000=0.14875 \mathrm{~kg} / \mathrm{s}=535.5 \mathrm{~kg} / \mathrm{h}=12,852 \mathrm{~kg} / \mathrm{d}$

The same data for natural gas density can be applied, and the natural gas consumption can be divided for generating $\mathrm{P}=3.7 \mathrm{MW}$ of electricity with the natural gas density with the following calculation:

$g_{P}=g_{2 m} / \rho$

where:

$g_{2 m}$ - natural gas consumption for generating $\mathrm{P}=3.7 \mathrm{MW}$ of electrical energy produced with the SOFCs $[\mathrm{kg} / \mathrm{s}]$,

$\rho$ - natural gas density $\left[\mathrm{kg} / \mathrm{m}^{3}\right]$ at $\mathrm{p}_{\text {atm. }}$ and $15^{\circ} \mathrm{C}$

$g_{2 v}=12,852 / 530=24.25 \mathrm{~m}^{3} / \mathrm{d}$

Consequently, it can be concluded that the overall natural gas consumption for generating $\mathrm{P}=3.7 \mathrm{MW}$ of electrical energy produced with the SOFC amounts to $24.25 \mathrm{~m}^{3} / \mathrm{d}$.

For generating electrical energy produced with the SOFC, we consume $\mathrm{g}_{2 \mathrm{~m}}=535.5 \mathrm{~kg} / \mathrm{h}$ of natural gas, and the calorific value of natural gas is $\mathrm{Hg}=55,550 \mathrm{~kJ} / \mathrm{kg}$ [26]. Therefore, by multiplying these two values, we get the amount of the input power:

$P_{2}=g_{2 m} * H_{g}=535.5 * 55,550=29,747,025 \mathrm{~kJ} / \mathrm{h}=8,263.1 \mathrm{~kW}=8.26 \mathrm{MW}$

If we divide the required power $\mathrm{P}=3.7 \mathrm{MW}$ with the input power $\mathrm{P}_{2}=8.26 \mathrm{MW}$, we get a solid oxide fuel cell energy conversion efficiency:

$\eta_{E L 2}=P / P_{2}=3.7 / 8.26=0.448$ 


\subsection{Using of thermal energy generated during a SOFC activity}

As mentioned earlier, the heat generated during the activity of a SOFC would be partly used for preheating the air before entering the fuel cell, and partly for generating a lower pressure steam in a somewhat smaller heat exchanger (low pressure steam generator), by which a certain amount of energy generated by the steam generator for its own purposes would be saved. The lower pressure steam from this generator is used for heating fuel tanks, oil tanks and crew areas, for heating fuel, water, glycol and separating oil, and for heating air before entering the steam generator.

Based on [31], the graph in Figure 5 shows the steam amount that needs to be brought to a steam generator for generating lower pressure steam, and the overall quantity of steam produced in main boilers during various compressed air discharge flows through a regasification unit.

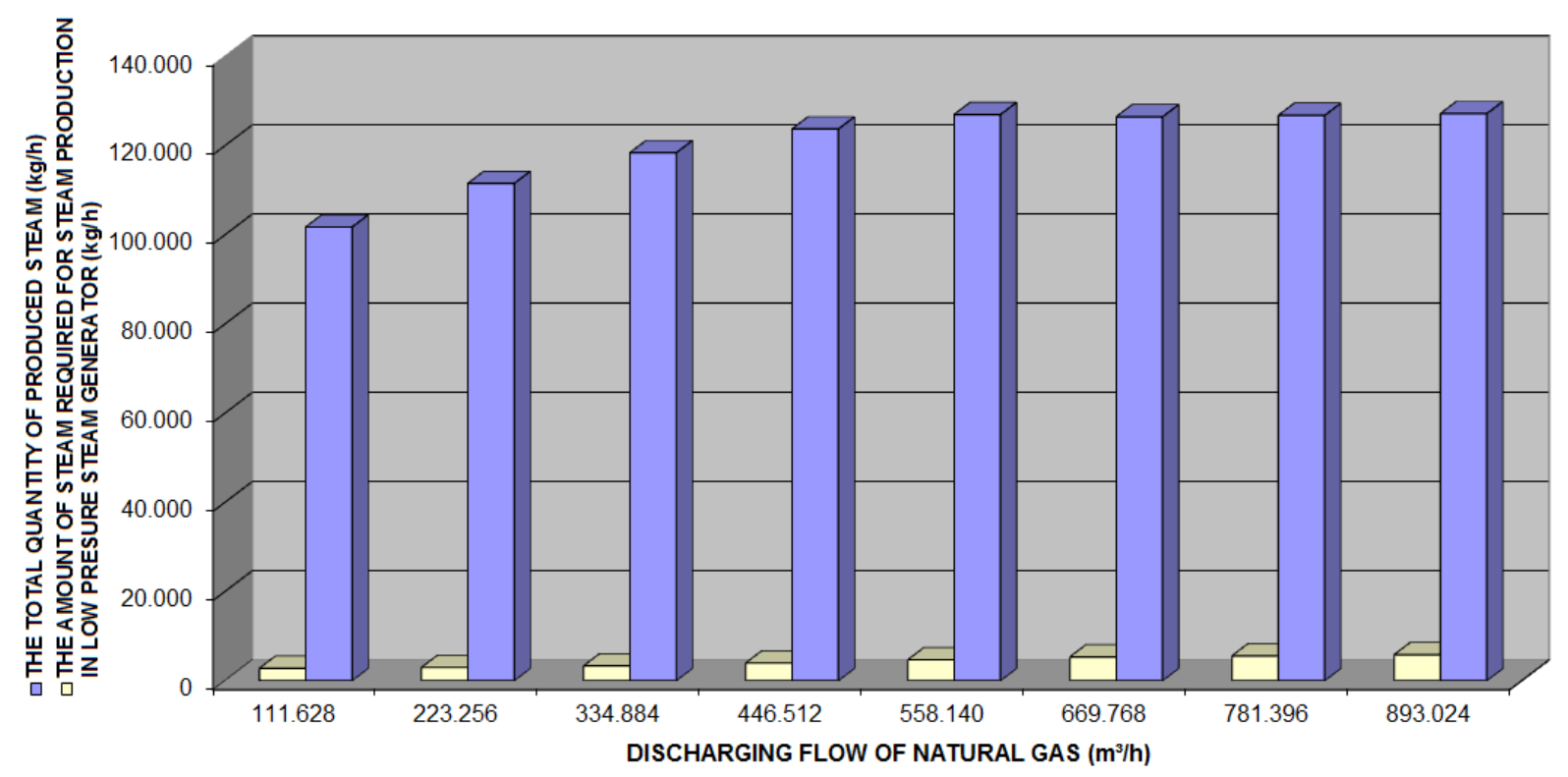

Fig. 5. The amount of steam required for steam production in a low pressure steam generator and the total amount of steam generated in the main boilers as a function of discharging flow of natural gas

\subsection{Calculation of the thermal energy generated during a SOFC activity}

The thermal energy generated during an SOFC activity with the power of $\mathrm{P}=3.7 \mathrm{MW}$ and the working temperature of $800{ }^{\circ} \mathrm{C}$, with $50 \%$ steam reformation of the natural gas and $50 \%$ recirculation of the anode exhaust gases totals [30]:

$P_{H E}=P\left(\left(1.25 / V_{c}\right)-1\right)$

where:

$P$ - electrical energy from the SOFC $[\mathrm{kW}]$,

$V_{c}$ - voltage of the single SOFC [V],

$P_{H E}=3,700,000((1.25 / 0.98)-1)=1,019,387.75=1.02 \mathrm{MW}$ 
From this, it can be concluded that, during the activity of an SOFC the power of $\mathrm{P}=3.7$ $\mathrm{MW}$, the thermal energy of $\mathrm{P}_{\mathrm{HE}}=1.02 \mathrm{MW}$ is generated. This energy will be used partly for preheating air before entering the fuel cell, and partly for generating lower pressure steam. On the other side, the total quantity of the thermal energy generated increases during the activity of 3 turbo generators, and amounts to $\mathrm{P}_{\mathrm{HE} 3}=3.06 \mathrm{MW}$.

For the purpose of generating low pressure steam, it is necessary to generate $5,835 \mathrm{~kg} / \mathrm{h}$ of superheated steam in the main boilers. For generating $5,835 \mathrm{~kg} / \mathrm{h}$ of superheated steam, we use $g_{P 2}=350 \mathrm{~kg} \mathrm{~h}^{-1}$ of natural gas, and the heat value of natural gas is $\mathrm{H}_{\mathrm{g}}=55,550 \mathrm{~kJ} / \mathrm{kg}$. Therefore, by multiplying these two values, we get the value of the input power [26]:

$P_{H E A T 1}=g_{P 2} * H_{g}$

$P_{\text {HEATI }}=350 * 55,550=19,442,500 \mathrm{~kJ} / \mathrm{h}=5,400.69 \mathrm{~kW}=5.4 \mathrm{MW}$

The heat necessary for preheating air before entering an SOFC was not taken into consideration in this study due to its insignificance [30]. If we divide the thermal energy gained by the activity of 3 SOFCs, each of the power of $\mathrm{P}=3.7 \mathrm{MW}$ at the working temperature of $800{ }^{\circ} \mathrm{C}$, with the thermal energy needed for the low pressure steam generator to operate, we get the overall degree of the thermal energy efficiency:

$\eta_{H E 1}=P_{H E 3} / P_{H E 1}$

$\eta_{H E 1}=3.06 / 5.4=0.567$

Part of this heat energy is used to preheat the inlet air into the main boilers and the rest is used to heat the low pressure steam boiler. A low pressure steam boiler produces steam to be used for heating fuel and lubricating oil, fuel tanks, oil tanks, and heating air for accommodation on board.

\section{Conclusion}

The aim of this paper was to analyse energy efficiency when replacing the existing turbo generators by the Solid Oxide Fuel Cells (SOFCs). Instead of three turbo generators (each of the power of $3,700 \mathrm{~kW}$ ), three SOFCs (each of the power of 3,700 kW) would be installed in the steam plant for producing electrical energy to improve efficiency.

When using the SOFC system, the energy conversion efficiency amounts to $44.8 \%$, while it totals $32.9 \%$ when using a steam generator.

Furthermore, by using the SOFC system, the generated thermal energy can be used, as described in this article, and the savings would amount to about $2.6 \%$ of the overall natural gas consumption, depending on the natural gas discharge flow.

It is important to point out that the estimation of electrical energy generation was performed for one steam generator and for the SOFC system with the power of 3.7 MW, while the estimation of thermal energy generation was based on the usage of three steam generators.

This research provides an innovative solution to convert natural gas from liquid to gas for a new generation of LNG carriers with the regasification unit. These days the LNG carriers, that are being built, have great needs for electrical energy.

Further research should include different main propulsion technologies and an open, combined or closed cycle together with steam heaters during the regasification operation.

\section{References:}

[1] https://www.lngjournal.com/index.php/latest-journal-pdf/download/50-2018/727-lng-journal-2018-01january(Accessed on February 09 2018). 
[2] https://www.lngjournal.com/index.php/downloads/send/52-2018/739-122-lng-shipping-news-feb-1 (Accessed on February 09 2018).

[3] Attah E.E., Bucknall R. An analysis of the energy efficiency of LNG ships powering options using the EEDI, Ocean Engineering 110(2015), pp. 62-74. https://doi.org/10.1016/j.oceaneng.2015.09.040

[4] DSME. LNGRV Exquisite Regas Operational Manual, Okpo Shipyard, Korea, 2010. http://www.pfst.unist.hr/hr/?option=com_intranet\&task=download\&format=raw\&fid=3221

[5] http://www.photographersdirect.com/buyers/stockphoto.asp, (Accessed on March, 17 2015).

[6] Kwak D.H., Heo J.H., Park S.H., Seo S.J., Kim J.K. Energy-efficient design and optimization of boil-off gas (BOG) Re-liquefaction process for LNG-fuelled ship, Energy (2018), doi:10.1016/j.energy.2018.01.154. https://doi.org/10.1016/j.energy.2018.01.154

[7] Van Biert L., Godjevac M., Visser K., Aravind P.V. A review of a fuel cell system for marine applications, Journal of Power Sources 327(2016), pp. 345-364. https://doi.org/10.1016/j.jpowsour.2016.07.007

[8] Welaya, Y. M. A., Mosleh, M., Ammar, N. A., Thermodynamic analysis of a combined solid oxide fuel cell with a steam turbine power plant for marine applications, Brodogradnja 65 (1)(2014), pp. 97-116.

[9] Mohamed M. El Gohary Nader R. Ammar Ibrahim S. Seddiek, Steam and SOFC based reforming options of PEM fuel cells for marine applications, Brodogradnja 66 (2), (2015), pp. 61-76.

[10] Fontell E., Kivisaari T., Christiansen N., Hansen J.B., Palsson J. Conceptual study of a $250 \mathrm{~kW}$ planar SOFC system for CHP application, Journal of Power Source 131(2004), pp. 49-56. https://doi.org/10.1016/j.jpowsour.2004.01.025

[11] Diaz-de-Baldasano M.C., Mateos F.J., Nunez-Rivas L.R., Leo T.J. Conceptual design of offshore platform supply vessel based on hybrid diesel generator-fuel cell power plant, Applied Energy 116(2014), pp. 91-100. https://doi.org/10.1016/j.apenergy.2013.11.049

[12] Douvartzides S., Coutelieris F., Tsiakaras P. Energy analysis of a solid fuel cell power plant fed by either ethanol or methane, Journal of Power Sources 131(2004), pp. 224-230. https://doi.org/10.1016/i.jpowsour.2003.10.015

[13] Morosuk T., Tsatsaronis G. Comparative evaluation of LNG - based cogeneration systems using advanced exergic analysis, Energy 36(2011), pp. 3771-3778. https://doi.org/10.1016/j.energy.2010.07.035

[14] Hotz N., Senn S.M., Poulikakos D. Energy analysis of a solid oxide fuel cell micropowerplant, Journal of Power of Source 158(2006), pp. 333-347. https://doi.org/10.1016/j.jpowsour.2005.09.023

[15] Bavarsad P.G. Energy and exergy analysis of internal reforming solid oxide fuel cell-gas turbine hybrid system, International Journal of Hydrogen Energy 32(2007), pp. 4591-4599. https://doi.org/10.1016/j.ijhydene.2007.08.004

[16] Boyano A., Morosuk T., Blanco-Marigorta A.M., Tsatsaronis G. Conventional and advanced exergoenvironmental analysis of a steam methane reforming reactor for hydrogen production, Journal of Cleaner Production 20(2012), pp. 152-160. https://doi.org/10.1016/j.jclepro.2011.07.027

[17] Boyano A., Blanco-Marigorta A.M., Morosuk T., Tsatsaronis G. Exergoenvironmental analisys of a steam methane reforming reactor for hydrogrn production, Energy 36(2011), pp. 2202-2214. https://doi.org/10.1016/j.energy.2010.05.020

[18] Alvarez T., Valero A., Montes J.M. Thermodinamic analysis of a fuel cell hybrid power system from the fuel cell experimental data, Energy 31(2006), pp. 1358-1370. https://doi.org/10.1016/j.energy.2005.05.030

[19] Gomez M.R., Garcia R.F., Gomez J.R., Carril J.C. Thermodynamic analysis of a Brayton cycle and Rankine cycle arranged in series exploiting the cold exergy of LNG (liquefied natural gas), Energy 66(2014), pp. 927937. https://doi.org/10.1016/j.energy.2013.12.036

[20] Petrakopoulou F., Tsatsaronis G., Morosuk T., Carassai A. Conventional and advanced exergetic analysis applied to a combined cycle power plant, Energy 41(2012), pp. 146-152. https://doi.org/10.1016/j.energy.2011.05.028

[21] Tsatsaronis G., Morosuk T. Advanced exergetic analysis of a novel system for generating electricity and vaporizing liquefied natural gas, Energy 35(2010), pp. 820-829. https://doi.org/10.1016/j.energy.2009.08.019

[22] Cheddie D.F. Integration of a solid oxide fuel cell into a $10 \mathrm{MW}$ gas turbine power plant, Energies 3(2010), pp. 754-769. https://doi.org/10.3390/en3040754

[23] Williams G.J., Siddle A., Pointon K. Design optimization of a hybrid solid oxide fuel cell \& gas turbine power generation system, Crown Copyright: ALSTOM Power Technology Center, 2001. 
[24] Khaljani M., Khoshbakhti Saray R., Bahlouli K. Comprehensive analysis of energy, exergy and exergoeconomic of cogeneration of heat and power in a combined gas turbine and organic Rankine cycle, Energy Conversion and Management 97(2015), pp. 154-165. https://doi.org/10.1016/j.enconman.2015.02.067

[25] Martinic F. Energy consumption in the conversion of liquid natural gas in gaseous state on LNG carriers, Naše more Vol 58 No.5-6(2011), pp. 206-211.

[26] DSME. Machinery operating manual, Engineering data of main equipment, Okpo Shipyard, Korea, 2010. http://www.pfst.unist.hr/administrator/index.php?option=com_intranet\&view=sskolegijmaterijal\&layout=edi $\underline{\mathrm{t} \& \mathrm{id}=2761}$

[27] Lisbona P., Corradetti A., Bove R., Lunghi P. Analysis of a solid oxide fuel cell system for combined heat and power applications under non-nominal conditions, Electrochimica Acta 53(2007), pp. 1920-1930. https://doi.org/10.1016/j.electacta.2007.08.046

[28] Chan M.S.H., Ho H.K., Tian Y. Modeling of simple hybrid solid fuel cell and gas turbine power plant, Journal of Power Sources 109(2002), pp. 111-120. https://doi.org/10.1016/S0378-7753(02)00051-4

[29] Bove R., Ubertini S. Modeling solid oxide fuel cell operations, approaches, techniques and results, Journal of Power Sources 159(2006), pp. 543-559. https://doi.org/10.1016/j.jpowsour.2005.11.045

[30] Larminie J., Dicks A. Fuel Cell Systems Explained, The Atrium, Chichester, 2003. https://doi.org/10.1002/9781118878330

[31] Ono Y., Uchida I. Main boiler (MB-4E-KS2)-Boiler instruction and maintenance manual (I), Mitsubishi Heavy Industries, LTD., Nagasaki, Japan, 2009. http://www.pfst.unist.hr/hr/?option=com intranet\&task=download \&format=raw\&fid=3220

[32] Matsushita K. Final drawing \& instruction book, Mitsubishi boiler printed, Japan, 2002.

[33] Hiller M., Hine L. LNG Unlimited. International Press Centre, UK, 2008.

[34] Ozretić V. Brodski pomoćni strojevi i uređaji, SSM-Split, Split, 1996.

[35] Kawasaki. Final drawing \& instruction book, Kawasaki turbine, Japan, 2002.

[36] Coats R., Mar F., Mech M., Weld M. Marine steam turbines (Part 8), Institute of Marine Engineers, London, 1984.

[37] Huang K., Goodenough J.B. Solid oxide fuel cell technology, Woodhead Publishing Limited and CRC Press LLC, Boca Raton, 2009. https://doi.org/10.1533/9781845696511

[38] Carlson E.J., Yang Y., Fulton C. Solid oxide fuel cell manufacturing cost model: Simulating relationships between performance, manufacturing, and cost of production, TIAX LLC, Cambridge, Massachusetts, 2004. https://doi.org/10.2172/828876

[39] Ciesar J.A. Hybrid system development by the Siemens Westinghouse Power Corporation: Stationary fuel cells, Siemens, Pittsburg, Pennsylvania, 2001.

[40] Shin'ya O., Itaru T. Exergy analysis of a regional-distributed PEM fuel cell system, International Journal of Hydrogen Energy 33(2008), pp. 2300-2310. https://doi.org/10.1016/j.ijhydene.2008.02.036

[41] Williams G.J., Siddle A., Pointon K. Design optimization of a hybrid solid oxide fuel cell \& gas turbine power generation system, Crown Copyright: ALSTOM Power Technology Center, 2001.

[42] Group of Authors. Scale-up planar SOFC stack technology for MW-level combined cycle system, TIAX LLC, Cambridge, Massachusetts, 2003.

[43] Minh N. Solid oxide fuel cell technology: Features, Status, and application. Clean energy, Boston, Massachusetts, 2007.

[44] Schinas O., Butler M. Feasibility and commercial considerations of LNG-fueled ships, Ocean Engineering 122(2016), pp. 84-96. https://doi.org/10.1016/j.oceaneng.2016.04.031

[45] Kana A.A., Harrison B.M.. A Monte Carlo approach to the ship-electric Markov decision process for analyzing decisions over converting a containership to LNG power, Ocean Engineering 130(2017), pp. 4048. https://doi.org/10.1016/j.oceaneng.2016.11.042

Submitted: 04.05.2018. Mag. Ing. Frane Martinić, Ph.D. candidat, fmartinic@ yahoo.com

$\mathrm{Ph}$. D. Gojmir Radica, professor, gojmir.radica@fesb.hr

Ph. D. Frano Barbir, professor, fbarbir@fesb.hr

Faculty of electrical engineering, mechanical engineering and naval architecture Ruđera Boškovića 32, 21000 Split 